\title{
The effect of irrigation water quality on soil properties under center pivot irrigation systems in central Saudi Arabia
}

\author{
H. M. Al-Ghobari \\ Agricultural Engineering Department, College of Food and Agricultural \\ Sciences, King Saud University, Saudi Arabia
}

\begin{abstract}
A field experiments were conducted for three growing seasons (2007 to 2009) at five different sites of soil types and salinity levels. Five different ground water qualities were used to irrigate five fields each with area of 50 to 54 hectares planted with wheat crop and the irrigation system used at each field was center pivot sprinkler system. The irrigated fields were located at different locations of Riyadh region in Saudi Arabia. The soil samples were taken at different depths $(10,20,40,60 \mathrm{~cm})$ from the soil surface at the beginning of season 2007 and at the end of season 2009.

The quality effect of irrigation water on each soil salinity at each depth was determined. The results showed that all irrigated fields have differed in salt concentration as indicated by soil electrical conductivity $\left(\mathrm{EC}_{\mathrm{e}}\right)$ values of the saturated paste extracts. The soil salinity in some fields decreased and increased in other soils, and the distribution of salts through the soil profile is highly correlated with the salinity of irrigation water and soil type. Saline water increased the soil salt content throughout the profile to a greater extent than nonsaline water. Thus, the salts accumulation in soil of field 4 and 5 was closely related to the salt concentration of irrigation water, and there was a progressive and significant increase in soil salinity values as the salinity of irrigation water increases. Also, the obtained results showed that the decrease or increase in soil salinity through the soil profiles for all fields occurred mainly at first season and slight increase in the following two seasons, and not with the increase of the number of seasons, and the soil salinity values remains closely the same and does not influenced by the prolonged use of low or high salinity waters for a number of years for all fields during the study.
\end{abstract}


Keywords: center pivot system, soil salinity, water quality, soil property, water applied, irrigation system, Saudi Arabia.

\section{Introduction}

Water is the most important resource and limiting factor for agricultural development in the arid regions in general and in Saudi Arabia in particular. Saudi Arabia is a country without any appreciable quantities of freshwaters and over $80 \%$ of the agricultural needs are currently met largely by the saline ground waters. Because of dry arid climate, most of the agricultural soils are saline and requires excess water to leach salts from plant root zone. The chemical characteristics of water in Saudi Arabia vary depending upon the geological formation of the aquifers. Irrigation waters contain salts in different amounts and proportions that will influence suitability for a specific use. Suitability of any irrigation water for agriculture depends mostly on its chemical composition and the conditions of use. The main factors determining the conditions of use are soil texture, total water salinity, crop to be irrigated, climate, management practices and the skill of the water user. Many researchers have reported on the evaluation of ground water quality for some regions of the country (Mee [1] and Al-Jaloud and Hussain [2]).

As the demand for water increases, an effective conservation of water and soil is of primary importance in any agricultural development. Therefore, methods or practices that increase water use efficiency, soil productivity and reduce the excessive amount of water applied are of importance for conserving water. The effect of the quality of irrigation water on soil properties has been discussed by many researchers [3-13]. Ragab [14] found that soil electrical conductivity $\left(\mathrm{EC}_{\mathrm{s}}\right)$ values increased with increasing salinity of irrigation water and decreased soil moisture depletion in calcareous soil. Also, Ragab [14] found that the increasing of irrigation salinity from 0.58 to 3.67 deciSiemens per metre $\left(\mathrm{dS} \mathrm{m}^{-1}\right)$ increased total soil salinity from 1.87 to $24.83 \mathrm{dS} \mathrm{m}^{-1}$. Thus, the salts accumulation in soil was closely related to the salts concentration of irrigation water. He observed [14] that, there was a progressive and significant increase in soil salinity values as the salinity of irrigation water increases. But, Mwenja [15] reported that the soil salinization does not entirely depend on water quality, and concluded that other factors, including level of water application, drainage, management practices, and some climactic factors influence salinization. Maggio et al. [11] reported that salinity reduced total plant water uptake and seemed to be a very important variable affecting total plant water uptake. Romic et al. [12] stated that influence of increasing salt concentrations in irrigation water using different irrigation systems (sprinkler and drip) in the watermelon production on plastic mulch. Crowley and Arpaia [16] showed that when the total dissolved salt concentrations in the soil solution exceed an electrical conductivity (EC) of $4 \mathrm{dS} \mathrm{m}^{-1}$, avocado trees are no longer able to extract water even if the soil is water saturated. Wenju et al. [17] found that the use of saline water causes the $\mathrm{EC}_{\mathrm{e}}$ of the top soil $(0-100 \mathrm{~cm})$ to be higher and more variable than the subsoil $(100-180 \mathrm{~cm})$. Also the use of poor quality water for irrigation could have 
detrimental effects on specific absorption rate (SAR), and EC. In order to prevent such problems or curtail further problems, Volschenk [4] showed that effects of salinity on soil properties are not restricted to low salinity and high SAR, but that clay dispersion may occur where irrigation water with a SAR of below or about 1 and EC of less than $0.1 \mathrm{dS} \mathrm{m}^{-1}$ is applied to soil. Kafi et al. [18] observed that growth stimulation by $15 \mathrm{dS} \mathrm{m}^{-1}$ salinity suggests that longer term field trials would be justified to evaluate the growth potential to reuse secondgeneration drainage water, saline and shallow ground waters, and even seawater for irrigation. Species with threshold of yield reduction well above the salinity of the irrigation water is needed (Khan et al. [19], Munns and Tester [20], Yensen and Biel [21]).

One of the important agricultural in the Saudi Arabia is the shortage of suitable sources of water besides balancing supply and demand while facing aridity and water scarcity, non-renewable supplies, poor quality of ground water, maldistribution of supplies, salt water intrusion, and over drafting and contamination of aquifers for agricultural purposes (Mohorjy and Grigg, [22]). The increasing demand for domestic, industrial, environmental and recreational water will force agriculturists to manage irrigation water carefully, contributing to environmental preservation. In parallel, brackish and saline water resources not used nowadays could be employed for irrigation if greater knowledge of salt tolerance and proper technology are developed.

Knowledge of the chemical composition of the water is necessary but not sufficient to evaluate its suitability for irrigation. Other factors such as climate, soil characteristics, drainage conditions and the irrigation method should be considered in order to define the appropriate land use and water management. In the near future, the limitation of water resources in the arid areas will be increased. Therefore, it is important to study the effect of using irrigation water of poor quality in agriculture. The challenge of the future will be to maintain or even increase water productivity with less water or with water with poor quality. The main objective of the study is to evaluate the effect of prolonged use of different salinity levels of irrigation water on soil salinity of different soil types under center pivot sprinkler irrigation system over three years period in the central region of Saudi Arabia.

\section{Materials and methods}

A number of field experiments were carried out and repeated during three successive seasons for wheat crop started from January, 2007 to May, 2009 at different private farms located in different areas of Riyadh region in the middle of Saudi Arabia. The region is classified as hot and dry with desert climate, and the average annual rainfall and evaporation about $50 \mathrm{~mm}$ and $4500 \mathrm{~mm}$ respectively. The irrigation system used in each field was center pivot sprinkler system and each system irrigates area ranged between 50 to 54 hectares. Soil sampling was done from five randomly selected sites in each field and repeated 
four times during the experiment, i.e. after layout of the experiment before planting (original soil) in January of each year, and at the end of May of each year. The five fields planted only wheat crop each year in the beginning of January until the mid of nearly May of each year. Then in September of each year the fields were ploughed and cultivated to prepare the fields for the next season for planting the wheat crops. Soil Samplings were taken at different depths from soil surfaces $(10,20,40$ and $60 \mathrm{~cm})$ to be analyzed. Composite samples were prepared from the soil samples collected from each field. Also, to determine the effect of prolonged use of different water quality levels on soil salinity under each center pivot sprinkler irrigation system at the end of each year. Also, particle-size analysis of the original soil for each field was carried out as shown in table 1. Data in table 1 showed that the types of soils in the fields were varied in their physical characteristics.

Table 1: $\quad$ Some physical characteristics of the studied soils in five fields.

\begin{tabular}{|c|c|c|c|c|}
\hline Field & Soil type & $\begin{array}{c}\text { Sand } \\
(\%)\end{array}$ & $\begin{array}{c}\text { Clay } \\
(\%)\end{array}$ & Silt (\%) \\
\hline A & Loamy sand & $83 \%$ & $15 \%$ & $2 \%$ \\
\hline B & Sandy clay & $53 \%$ & $42 \%$ & $5 \%$ \\
\hline C & Loamy sand & $86 \%$ & $12 \%$ & $2 \%$ \\
\hline D & Clay & $23 \%$ & $70 \%$ & $7 \%$ \\
\hline E & clay & $23 \%$ & $70 \%$ & $7 \%$ \\
\hline
\end{tabular}

The sources of irrigation water for all fields were waters pumped from a deep well located at each field. Water samples were collected from different spray nozzles along the lateral line of each center pivot system before planting of first season of 2007. The water samples were analyzed to determine its salinity and chemical compositions and all the major cations and anions were determined as shown in table 2. The salinity and sodicity hazards classification of irrigation waters was done according to the standards established by Ayers and Westcot [5]. The irrigation waters used in five fields were varied in their salinity levels for low saline water to high saline water, as demonstrated in table 2.

It should be mention that all fields during the study received non-uniform application of bio-fertilizers, and these fertilizes were nitrogen $(\mathrm{N})$, phosphate $\left(\mathrm{P}_{2} \mathrm{O}_{5}\right)$ and potassium $\left(\mathrm{K}_{2} \mathrm{O}\right)$ and the average applications of bio-fertilizers during the study ranged from 250-280 kg N/hectare, 150-225 $\mathrm{kg} \mathrm{P}_{2} \mathrm{O}_{5} /$ hectare and 40$100 \mathrm{~kg} \mathrm{~K} \mathrm{~K}_{2} \mathrm{O} /$ hectare respectively. These quantities of fertilizers were added three times for each field during each year and injected with irrigation water through the irrigation system. 
Table 2: Chemical composition of water used for irrigation in five fields.

\begin{tabular}{|c|c|c|c|c|c|c|c|c|c|c|}
\hline \multirow{2}{*}{ Field } & \multirow{2}{*}{$\mathrm{pH}$} & $\mathrm{S} A R$ & \multirow{2}{*}{$\mathrm{EC}_{\mathrm{iw}}$} & \multicolumn{6}{|c|}{ Milli equivalents per litre ( meq/l) } \\
\cline { 5 - 11 } $\mathrm{A}$ & 6.87 & 2.66 & 0.46 & 0.10 & 2.00 & 2.35 & 0.66 & 0.90 & 1.00 & 1.69 \\
\hline $\mathrm{B}$ & 6.52 & 1.06 & 1.40 & 0.10 & 3.00 & 7.10 & 4.26 & 2.52 & 9.21 & 2.54 \\
\hline $\mathrm{C}$ & 7.72 & 2.16 & 2.44 & 0.21 & 8.00 & 9.50 & 5.33 & 3.79 & 5.00 & 10.73 \\
\hline $\mathrm{D}$ & 7.2 & 2.40 & 5.02 & 0.21 & 14.00 & 12.25 & 11.07 & 4.48 & 32.08 & 11.30 \\
\hline $\mathrm{E}$ & 7.13 & 3.03 & 6.55 & 0.31 & 26.52 & 35.00 & - & 2.20 & - & 19.97 \\
\hline
\end{tabular}

\section{The results and discussions}

The effect of prolonged use of different water quality levels; $\mathrm{EC}_{\mathrm{iw}}$ on Soil salinity under each center pivot sprinkler irrigation system was investigated. The average water salinity levels used for irrigation water were $0.46 \mathrm{dS} \mathrm{m}^{-1}$ for field A, $1.4 \mathrm{dS} \mathrm{m}^{-1}$ for field $\mathrm{B}, 2.44 \mathrm{dS} \mathrm{m}^{-1}$ for field C, $5.02 \mathrm{dS} \mathrm{m}^{-1}$ for field D and $6.55 \mathrm{dS} \mathrm{m}^{-1}$ for field $\mathrm{E}$. The $\mathrm{EC}_{\mathrm{e}}$ values of soils at each depth before planting and after harvesting for each season for three years at different depths were determined and presented in fig. 1. Figure 1 shows the effect of irrigation water salinity; $\mathrm{EC}_{\mathrm{iw}}$ on soil salinity; $\mathrm{EC}_{\mathrm{e}}$ for different soil types throughout the soil profiles for three successive seasons of wheat crops in five fields under center pivot sprinkler irrigation systems. In fig. 1, it can be seen that the $\mathrm{EC}_{\mathrm{e}}$ values of the original soil before planting (before the first season of 2007) were high at all depths for fields A, B and C, but at end of first season, the soil salinity was decreased in these fields remarkably to lower values at all depths. This decrease in soil salinity in each soil depth varied from field to another, but the soil surface depths $(0.1 \mathrm{~m})$ for fields $\mathrm{A}, \mathrm{B}$ and $\mathrm{C}$ have less soil salinity compared to lower depths $(0.2-0.6 \mathrm{~m})$. This could be attributed to the increase effect of irrigation water salinity on the top soil surface depth $(0.1 \mathrm{~m})$ compared to the lower depths.

However, fig. 1 also, showed that the $\mathrm{EC}_{\mathrm{e}}$ values of the original soil before planting of 2007 were low at all depths for fields D and E, but after the first season the soil salinity was increased in these fields remarkably to higher values at all depths. Also, it can be noticed that the surface depths in these two fields have the higher values of soil salinity than the other depths $(02-0.6 \mathrm{~m})$, but varied from location to another. Also, the increase in the soil salinity throughout the soil depths was high during the first season and slight increase in the following two seasons, however, the remarkable increase can be noticed at the surface $0.1 \mathrm{~m}$ depth. The concentration of salts in the upper horizons of the profiles was due to evaporation of water from the salts applied in irrigation water and the irrigation waters used in both fields (D and E) have high water salinities 
and the soil type in both fields were clay soil. The salt build up will be increased with heavy soil texture which restricts water movement through the soil profile as in the fields $\mathrm{D}$ and $\mathrm{E}$.
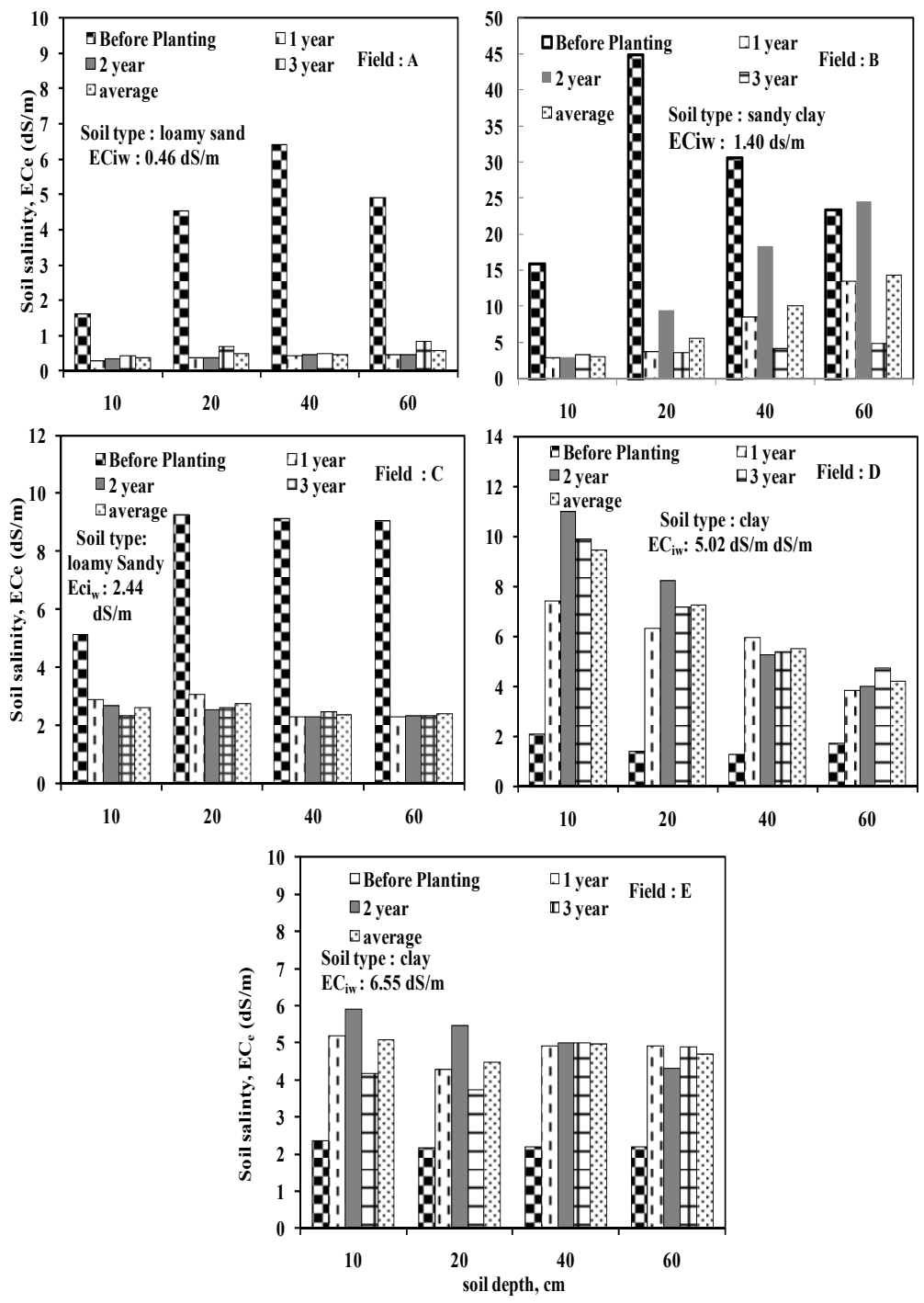

Figure 1: Effect of irrigation water salinity on soil salinity at different soil depths in five fields for three years.

Also, fig. 2 showed the comparison between the soil salinity for each field before the planting of first season 2007 and the average of soil salinity levels during the three seasons through the soil depths $(10,20,40$ and $60 \mathrm{~cm})$ for five fields. Figure 2 revealed that irrigation water salinity affected the soil salinity 
levels, either by decreasing soil salinity in fields A, B and C, and increasing it in fields D and E. The variations in soil salinity levels depend mainly on water salinity, soil type and other factors such as leaching requirement added during irrigation, climate, soil characteristics and drainage conditions should be considered. Therefore, the results presented in fig. 1 and fig. 2 for fields A, B and $\mathrm{C}$ showed that the irrigation with low levels of saline water $\left(0.46 \mathrm{dS} \mathrm{m}^{-1}\right.$ to $2.44 \mathrm{dS} \mathrm{m}^{-1}$ ) resulted in the decrease of soil salinity throughout the soil profiles for all fields. This decrease in soil salinity levels indicated the soil salinity was improved and this may be due to the amount of leaching requirements was high and the irrigation water used has low salinity levels to some extent in the three fields.
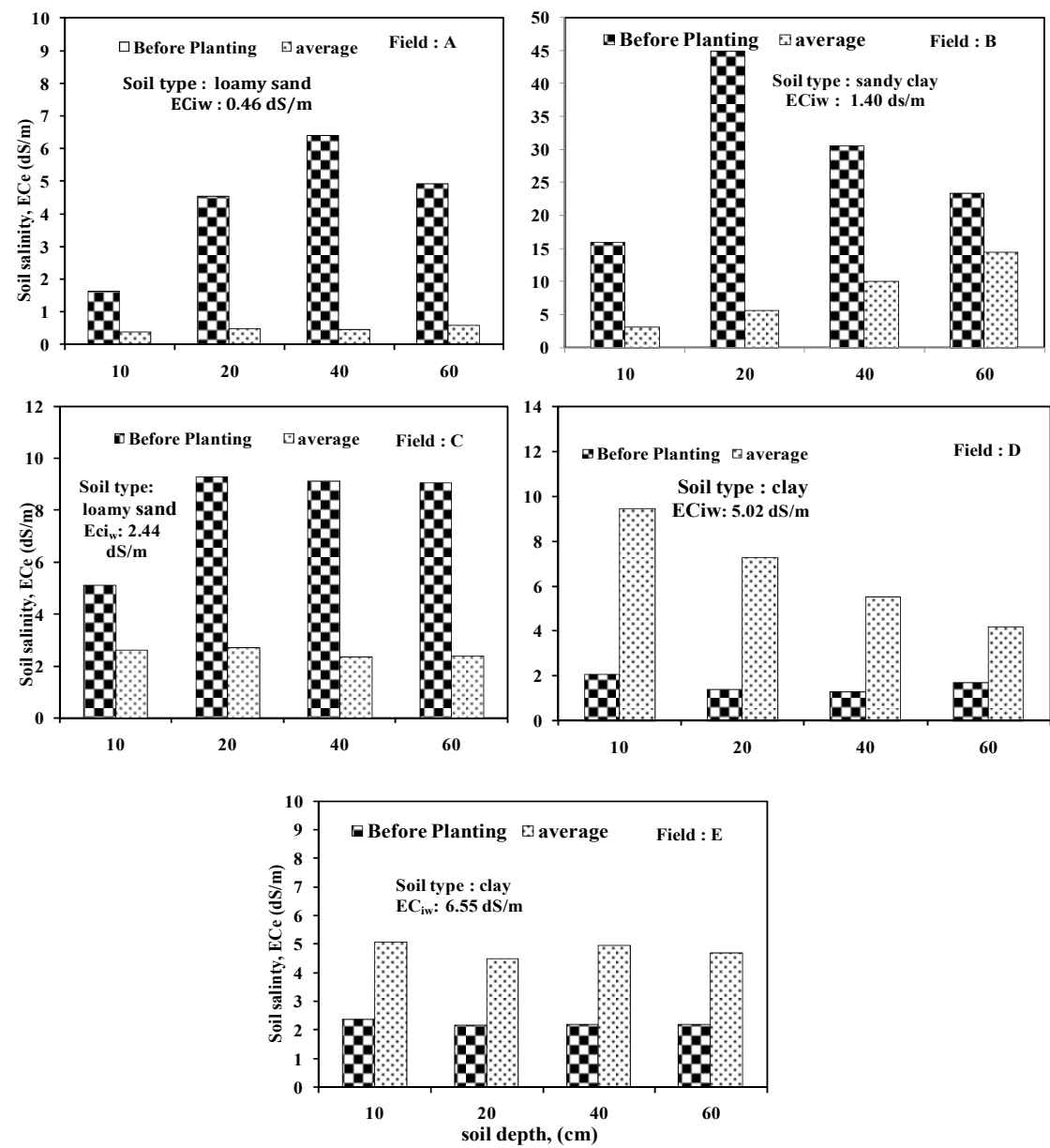

Figure 2: Effect of irrigation water salinity on the average of soil salinity for three years at different soil depths in five fields. 
Also, fig. 1 and fig. 2 revealed that the irrigation with high levels of saline water $\left(5.02 \mathrm{dS} \mathrm{m}^{-1}\right.$ to $\left.6.55 \mathrm{dS} \mathrm{m}^{-1}\right)$ resulted in the increase of soil salinity throughout the soil profiles for fields D and E. However, the obtained results showed that the soil salinity values remains closely the same and does not influenced by the prolonged use of low salinity waters for a number of years for all fields during the study. The concentration of salts in the upper horizons of the profiles was due to evaporation of water from the salts applied in irrigation water and the irrigation waters used in both fields (D and E) have high water salinities and the soil type in both fields were clay soil.

\section{Conclusion}

In this study, field experiments were conducted to study the effect of different water qualities on soil salinity for different soil types for three years under center pivot sprinkler irrigation system.

The results of the study showed that there were differences in the effect of water quality on soil salinity depending on the irrigation water quality and quantity, soil type and leaching requirement. In fact, there was a decrease in salt concentrations with some soils as indicated by $\mathrm{EC}_{\mathrm{e}}$ of soils in field $\mathrm{A}, \mathrm{B}$ and $\mathrm{C}$ throughout the soil profiles. This rate of salt decrease is related to the value of $\mathrm{EC}_{\mathrm{iw}}$, and the high rate decrease in soil salinity at field $\mathrm{A}$ was due to receiving irrigation water with less salinity $\left(0.46 \mathrm{dS} \mathrm{m}^{-1}\right)$. Also, the results showed that this high decrease in soil salinity through the soil profiles occurred mainly at first season and not with increase of the number of seasons. Also, the high rate of salt increase accumulated in the soil profiles at fields D and E was due to the irrigation of high saline water, and this increase was noticeable at the surface 0.1 $\mathrm{m}$ depth. This increase of soil salinity indicates that the effect of poor water quality on soil salinity was caused by the build up of the salts throughout the soil profiles. The salt build up will be increased with heavy soil texture which restricts water movement through the soil profile as in the fields D and E.

Also, the obtained results showed that the decrease or increase in soil salinity through the soil profiles for all fields occurred mainly at first season and slight increase in the following two years, and not with the increase of the number of years, and the soil salinity values remains closely the same and does not influenced by the prolonged use of low or high salinity waters for a number of years for all fields during the study.

It is concluded that the selection of water quality, leaching requirements and soil type is very important to avoid major management problems. Also, It can be drawn from these results that under the local conditions, the level of salinity of irrigation water below $2.5 \mathrm{dS} \mathrm{m}^{-1}$ can be used for agriculture without major detrimental effect on wheat crop, but at higher salts concentration in irrigation water crop and soil will be affected and then more considerations should be taken. 


\section{References}

[1] Mee, J. M., Saudi ground water chemistry and its significance. Arab Gulf journal of scientific research, vol. $1: 113-120,1983$.

[2] Al-Jaloud, A. A \& Hussain, G., Water quality of different aquifers in Saudi Arabia and its predictive effects on soil properties. J. Arid soil research and rehabilitation, vol. 7 , pp. 85-101, 1993.

[3] Richards, L. A., Diagnosis and improvement of saline and alkali soils. USDA Agric. Handbook, No. 60, Washington, 1954.

[4] Volschenk. T., The effect of saline irrigation on selected soil properties, plant physiology and vegetative and reproductive growth of plsteyn apricots. Ph.D. Thesis, Fac. of Agric. (soil science) Univ. Stellenbosch .South Africa, 2005.

[5] Ayers, R.S, \& Westcot, D.W., Water quality for agriculture. FAO Irri.\& Drain. 29. Rome. 13-56, 1985.

[6] Burkhalter; J. \& Gates, T., Evaluating Regional Solutions to Salinization and Waterlogging in an Irrigated River Valley. J. Irrg. Drain. Eng., Vol. 132 (1) :21-32, 2006.

[7] Rhoades, J. D. \& Loveday, J., Salinity in irrigated agriculture. In B. A. Stewart and D. R. Nielsen (ed.) irrigation of agricultural crops. Agron. Monogr. 30 : 1042-1089, 1990.

[8] Cuartero, J. \& Munoz, R. F., Tomato and salinity. Scientia Horticulturae ,78. PP. 83-125, 1999.

[9] Dorias, M., Papadopoulos, A.P., \& Gosselin, A., Influence of electric conductivity management on greenhouse tomato yield and fruit quality. Agronomy. 21. pp. 367-383, 2001.

[10] Pitman, M.G., \& Lauchli, A., Global impact of salinity and agricultural ecosystems. In: Salinity: Environment-Plants Molecules. Eds. A. Lauchli, V. Luttge, Kluwer, The Netherlands, 3 -20, 2002.

[11] Maggio, A., Angelino, S. \& Barbieri, C., Physiological response of tomato to saline irrigation in long term salinezd soils. Eur. J. Agron.21. PP. 149159, 2004.

[12] Romic, D.,O. Gabrijel, R., Marija,V., Mijo. A. \& Dragutin, P., Salinity and Irrigation Method Affect Crop Yield and Soil Quality. ICID 21st European Regional Conference. 15-19 May - Frankfurt - Germany, 2005.

[13] Galvani, A., The challenge of the food sufficiency through salt tolerant crops. Rev Environ Sci Biotechnol, 6:3 -16, 2007.

[14] Ragab, A. A.M., Physical properties of some Egyptian soils. Ph.D. Thesis, Fac. of Agric. Cairo Univ., Egypt, 2000.

[15] Mwenja, A., Saline irrigation effect on some soil physical and chemical properties .MSc. Thesis, Fac. of Agric.(soil science), Texas University, Texas. U. S. A., 2000.

[16] Crowley, D. \& M, Arpaia, Salinity chloride interactions and their influence on Avocado yield. Production Research Report. Management and Physiology. 2008. 
[17] Wenju, M., Yu, Z. \& Mao, Z., Effects of saline water irrigation on soil salinity and yield of winter wheat-maize in North China Plain. Irrig Drainage Syst, 22:3-18, 2008.

[18] Kafi, M., H., Asadi, A. \& Ganjeali, A., Possible utilization of high-salinity waters and application of low amounts of water for production of the halophyte Kochia scoparia as alternative fodder in saline agroecosystems. J. Agric. Water .Management, 97 (1): 139-147, 2010.

[19] Khan, M.A., Ansari, R., Ali, H., Gul, B. \& Nielsen, B.L., Panicum turgidum, a potentially sustainable cattle feed alternative to maize for saline areas. Agric. Ecosys. Environ. 129, 542-546, 2009.

[20] Munns, R. \& Tester, M., Mechanism of salinity tolerance. Annu. Rev. Plant Biol. 59, 651-681, 2008.

[21] Yensen, N.P. \& Biel, K.Y., Soil Remediation Via Salt-conduction and the Hypotheses of Halosynthesis and Photoprotection, Tasks for Vegetation Science Series-40. Ecophysiology of High Salinity Tolerant Plants, pp. 313-344, 2006.

[22] Mohorjy, A. M. \& Grigg, N. S., Water resources management system for Saudi Arabia. J. Water Resour. Plng. And mgmt. vol. 121(2) :205-215, 1995 